IZA DP No. 4171

The Impact of Parental Education on Earnings: New Wine in an Old Bottle?

John Hudson

John G. Sessions

May 2009 


\title{
The Impact of Parental Education on Earnings: New Wine in an Old Bottle?
}

\author{
John Hudson \\ University of Bath \\ John G. Sessions \\ University of Bath \\ and IZA
}
Discussion Paper No. 4171
May 2009

IZA

P.O. Box 7240

53072 Bonn

Germany

Phone: +49-228-3894-0

Fax: +49-228-3894-180

E-mail: iza@iza.org

Any opinions expressed here are those of the author(s) and not those of IZA. Research published in this series may include views on policy, but the institute itself takes no institutional policy positions.

The Institute for the Study of Labor (IZA) in Bonn is a local and virtual international research center and a place of communication between science, politics and business. IZA is an independent nonprofit organization supported by Deutsche Post Foundation. The center is associated with the University of Bonn and offers a stimulating research environment through its international network, workshops and conferences, data service, project support, research visits and doctoral program. IZA engages in (i) original and internationally competitive research in all fields of labor economics, (ii) development of policy concepts, and (iii) dissemination of research results and concepts to the interested public.

IZA Discussion Papers often represent preliminary work and are circulated to encourage discussion. Citation of such a paper should account for its provisional character. A revised version may be available directly from the author. 
IZA Discussion Paper No. 4171

May 2009

\section{ABSTRACT \\ The Impact of Parental Education on Earnings: New Wine in an Old Bottle?}

We examine the impact of parental education on the shape of an individual's experienceearnings profile. A number of factors suggest that parental education will affect the ability of an individual to translate labor market experience into earnings. Our empirical analysis of US data suggests that this is indeed the case. Higher parental education shifts the earnings profile significantly to the left - the profile of individuals with parents who both have 15 years of education peaks at 16 years of experience when their wages are 52\% (24\%) greater than those whose parents both have only 5 (10) years of education.

JEL Classification: J30, J31, J33

Keywords: parental education, human capital, earnings

Corresponding author:

John G. Sessions

Department of Economics and International Development

University of Bath

Bath, BA2 7AY

United Kingdom

E-mail: j.g.sessions@bath.ac.uk 


\section{Introduction}

Labour economists have amassed widespread, if not overwhelming, empirical evidence of a positive correlation between experience and earnings [see Polachek and Siebert (1992) for a survey]. The rationale for such a relationship has concentrated on two key theoretical explanations. $^{2}$ The human capital model attests that over time workers become more productive, and hence better remunerated, on account of investments in education and training. Upward sloping profiles simply reflect the returns to these investments [Becker (1975), Mincer (1974)].

Agency theory, in contrast, focuses on the divergence of interests and the asymmetry of information between principals and agents. Costly monitoring necessitates compensation schemes that induce workers to self-select behaviour the firm considers optimal. One such scheme is the back-loading of compensation to the later years of tenure. Such a profile punishes current period shirking and encourages workers to work efficiently over their employment-cycle [Lazear (1981)].

The empirical literature has attempted to differentiate between the two hypotheses by investigating how individual (e.g. education, gender, age) and / or firm (e.g. size, ownership, compensation scheme) attributes impact on the nature of this profile [see, for example, Murphy and Welch (1990), Kotlikoff and Gokhale (1992), Hellerstein and Neumark (1995), Brown and Sessions (2006)]. ${ }^{3}$ In this paper we investigate an interesting, yet hitherto unexplored, relationship vis. the effects of parental education on the shape of an individual's experience-earnings profile. Parents devote financial and other (e.g. time, attention) resources into raising their children, both of which are important to the development of human capital, and both of which are important conduits for the intergenerational transmission of social and economic status. Higher educated parents are likely to spend more time with their children and to play a greater role in school choice. [Feinstein and Symons (1999), Ermisch and Francesconi (2001), Dustmann (2004)]. ${ }^{4}$ They are also likely to provide more nutritious diets

\footnotetext{
${ }^{2}$ Alternative explanations do exist. In models of search, labor market experience increases the probability of a successful job match and, therefore, expected earnings [Burdett (1978), Ruhm (1991), Jacobson and LaLonde (1993), Manning (2000)]. Rising profiles are also posited to induce preferred forced saving amongst workers [Loewenstein and Sicherman (1991), Frank and Hutchens (1993)].

${ }^{3}$ Brown and Sessions (2006), for example, find that workers remunerated under performance related pay face significantly flatter profiles than their salaried counterparts, a result they attribute to the presence of agency considerations in the setting of the profile.

${ }^{4}$ Ashenfelter and Rouse (1998) show that up to $60 \%$ of the cross-sectional variation in schooling outcomes in their twins sample can be explained by (observable and unobservable) family factors
} 
for their children [Sausenthaler et al. (2007)]. Irrespective of the driving force underpinning the relationship between experience and earnings, it is not unreasonable to hypothesize parental education playing some role.

We explore these issues using data derived from the US National Longitudinal Survey of Young Men (NLSYM). The NLSYM began in 1966 with 5525 males aged 14-24 and continued with follow up surveys through to 1981 [see Card (1995)]. ${ }^{5}$ We estimate from this data a modified Mincerican relationship between an individual's (log) hourly wage and his/her labour market experience and education, allowing for the impact of parental education:

$\ln w_{i}=\alpha_{0}+\left(\alpha_{1}+\alpha_{5} \Phi_{i}\right) \operatorname{Exp}_{i}+\left(\alpha_{2}+\alpha_{6} \Phi_{i}\right) \operatorname{Exp}_{i}^{2}+\alpha_{3} E d_{i}+\alpha_{4} \mathrm{X}_{i}+\varepsilon_{i}$

$\operatorname{Exp}_{i}$ and $E d_{i}$ denote, respectively, the labour market experience and education of respondent $i, \Phi_{i}$ is some measure of the educational attainment of respondent $i$ 's parents, $\mathrm{X}_{i}$ is a vector of demographic and regional control variables and $\varepsilon_{i}$ is a random error term. ${ }^{6}$

It is well understood that measurement error in education and/or unobserved ability bias will render a correlation between education and the unobserved component of earnings [Griliches (1977)]. ${ }^{7}$ A consistent estimate of the return to education, $\alpha_{3}$, in equation (1) can be derived if some component of the $\mathrm{X}_{i}$ vector affects education but not earnings. The random assignment of schooling, for example, would permit estimation of (1) by instrumental variables. Without random assignment, however, it is necessary to identify a variable that affects education but not earnings. We follow Card (1995) here in employing the proximity of a two-year or four-year college to the respondent during their youth as just such a variable. Respondents who grow up in areas far away from colleges face a higher cost of education and, therefore, are likely to invest relatively less in education other things equal.

\footnotetext{
${ }^{5}$ The NLSYM data used by both Card (1995) and ourselves may be downloaded in stata via the command: 'use http://www.stata.com/data/jwooldridge/eacsap/card'.

${ }^{6}$ We would, ideally, prefer a measure of actual labor market experience (i.e. one that accounts for periods spent in unemployment or otherwise outside the labor force) and /or tenure within a specific firm. The constraints of our data, however, restrict us to a measure of potential labor market experience - see Table 1 following.

${ }^{7}$ A negative correlation between $\varepsilon_{i}$ and $E d_{i}$ in equation (1) would also occur if the true return to education varied across the population and if relatively less educated individuals enjoyed relatively higher returns to education. This would be the case if individuals with different rates of time discount invested in education until the marginal return to education equalled their rate of time discount [see Lang (1993) and Card (1995)].
} 
We therefore also estimate alternative versions of (1) in which education is instrumented through the regression:

$E d_{i}=\beta_{0}+\beta_{1} Z_{i}+\mu_{i}$

where the vector $Z_{i}$ contains those variables in $X_{i}$ as well as two zero-one dummy variables denoting whether the local labour market in which the respondent lived in 1966 contained a two-year or four-year accredited college. Finally, we note that if there is some error in our measurement of education, then there will also be some error in our measurement of (potential) labour market experience, since the latter is defined as Age - Education - 6. We again follow Card (1995) in therefore instrumenting both education and experience through the vector $Z_{i}$.

\section{Empirical Results}

Our data definitions, descriptive statistics and regression results are set out in Tables 1-3. Specification (1) of Table 3 - a modified Mincerian wage equation that includes measures of parental education, regional and family structure - reproduces almost exactly Card's (1995) results as set out in column (5) of his Table $2{ }^{8}$ Specification (2) adds to this regression the impact of parental education on experience. Both this variable and its square are statistically significant at the $1 \%$ level of significance with signs that suggest that parental education brings forward the impact of experience on earnings. Specification (3) estimates the regression allowing for the endogeneity of education, experience and experience squared. The results are reasonably robust, although neither experience nor experience squared are now significant. In Specification (4), the experience-squared term is dropped and now experience is significant. Overall, this would suggest that the nonlinearity of the Mincer equation with respect to education is perhaps most applicable to those with well-educated parents Respondents with less well-educated parents experience relatively little tailing-off in earnings as they gain more experience.

Figure 1 illustrates the impact of parental education on the Mincer curve. The impact consists of three effects: Firstly, there is a shift effect via the impact of the binomial dummy

\footnotetext{
${ }^{8}$ We include here individual measures of parental education (i.e. Father's Education, Mother's Education) as well the interaction between the individual measures (i.e. Father's Education * Mother's Education). This latter variable controls for the effects of differences between parents' education, other things equal.
} 
variables in the earnings equation. Secondly, there is the impact on the returns to experience via parental impact and parental impacted squared in these equations. And finally, there is the impact on education (and experience). This is illustrated in Specification (5) of Table 3, which sets out the reduced form equation for education. It is apparent here that both the years of education of the mother and the father impact positively on the education of the individual. The shape of the curve in Figure 1 is consistent with a hypothesis that links initial progress in the labour market to parental education. The figure suggests that two people with the same level of education enter the labour market with similar wages, but those with better-educated parents see their wages rise more rapidly. For example, if an individual's parents both have 15 years of education, then his/her wages peak after 16 years of experience when his/her wages are $52 \%$ (24\%) greater than someone whose parents both have only 5 (10) years of education. Wages then start to decline and when all workers have 25 years experience their wages have moved much closer together. ${ }^{9}$

\section{Final Comments}

Why does parental education have this impact on the Mincer equation? There are a number of possibilities. Firstly, parents may supplement the formal education process and more educated parents are able to do this more effectively. Thus, at the end of their formal education someone with well-educated parents is actually better educated than someone with less well-educated parents, even if they have the same formal qualifications. Over time, however, the importance of on-the-job knowledge becomes more important and this educational gap closes. Secondly, there is the potential importance of influence. Welleducated parents may also be well-connected parents, able to secure their children good jobs in firms where they are able to progress rapidly. Over time, as the firm and the labour market learns more about an individual's true worth, the earnings of people with similar formal qualifications begin to re-align.

\footnotetext{
${ }^{9}$ Caution should be exerted in extrapolating these curves as the maximum years of experience in Card's sample is 23 years. One possibility is that after a certain number of year's experience, the wages of all workers converge.
} 


\section{References}

Ashenfelter, O. and C. Rouse. (1998). 'Income, Schooling, And Ability: Evidence From A New Sample Of Identical Twins.’ Quarterly Journal of Economics, 113(1), pp. 253-284.

Becker, G. S. (1975). Human Capital. New York: Columbia University Press for National Bureau of Economic Research.

Brown, S. and J. G. Sessions. (2006). 'Some Evidence on the Relationship Between Performance Related Pay and the Shape of the Experience-Earnings Profile.' Southern Economic Journal, 72(3), pp. 660-676.

Burdett, K. (1978). 'A Theory of Employee Job Search and Quit Rates.' American Economic Review, 68(1), pp. 212-224.

Card, D. (1995). 'Using Geographic Variation in College Proximity to Estimate the Return to Schooling.' In Christofides, L. N., E. K. Grant, and R. Swidinsky (Eds.), Aspects of Labor Market Behaviour: Essays in Honour of John Vanderkamp. Toronto: University of Toronto Press.

Dustmann, C. (2004). 'Parental Background, Secondary School Track Choice and Wages.' Oxford Economic Papers, 56, pp. 209-230.

Ermisch, J. and M. Francesconi. (2001). 'Family Matters: Impacts of Family Background on Educational Attainments.’ Economica, 68(270), pp. 137-56

Feinstein. L. and J. Symons (1999). 'Attainment in Secondary Schools.' Oxford Economic Papers, 51, pp. 300321

Frank, R. H. and R. M. Hutchens. (1993). 'Wages, Seniority and the Demand for Rising Consumption Profiles.' Journal of Economic Behaviour and Organisation, 21, pp. 251-76.

Griliches, Z. (1977). 'Estimating the Returns to Schooling: Some Econometric Problems', Econometrica, 45, pp. 1-22.

Hellerstein, J. K. and D. Neumark. (1995). 'Are Earnings Profiles Steeper than Productivity Profiles? Evidence from Israeli Firm-Level Data.’ Journal of Human Resources, 30, pp. 89-112.

Jacobson, L., and R. J. LaLonde. (1993).'Earnings Losses of Displaced Workers.' American Economic Review, 83(4), pp. 685-709.

Kotlikoff, L. J. and J. Gokhale. (1992). 'Estimating a Firm’s Age-Productivity Profile Using the Present Value of Worker’s Earnings.' Quarterly Journal of Economics, 107, pp. 214-23.

Lang, K. (1993). 'Ability bias, Discount Rate Bias and the Return to Education.’ Discussion Paper, Department of Economics, Boston University.

Lazear, E. P. (1981). 'Agency, Earnings Profiles, Productivity and Hours Restrictions.' American Economic Review, 71, pp. 606-20.

Loewenstein, G. and N. Sicherman. (1991). 'Do Workers Prefer Increasing Wage Profiles?' Journal of Labor Economics, 9, pp. 437-54.

Manning, A. (2000). 'Movin' On Up: Interpreting the Earnings-Experience Profile.' Bulletin of Economic Research, 52, pp. 261-295.

Mincer, J. (1974). Schooling, Experience and Earnings. New York: Columbia University Press.

Murphy, K. and F. Welch. (1990). 'Empirical Age-Earnings Profiles.' Journal of Labor Economics, 8(2), pp. 202-229

Polachek, S. and W. Siebert. (1992). The Economics of Earnings. Cambridge: Cambridge University Press.

Ruhm, C. J. (1991). 'Are Workers Permanently Scared by Job Displacements.' American Economic Review, 81(1), pp. 319-324.

Sausenthaler. S, Kompauera. I, Mielcka. A, Bortea. M, Herbartha. O, Schaafa. B, von Berga. A and Heinrich. J. (2007). 'Impact of Parental Education and Income Inequality on Children's Food Intake.' Public Health Nutrition, 10, pp. 24-33 
Table 1: Data Definitions

\begin{tabular}{ll}
\hline \hline Variable & Definition \\
\hline Wage & Hourly wage rate \\
Age & Age in years \\
Education & Years of schooling \\
Experience & Age - Education - 6 \\
Black & Equals 1 If respondent is black \\
Father's Education & Father's years of schooling \\
Mother's Education & Mother's years of schooling \\
Parental Education (Interaction) & Father's Education * Mother's Education \\
Parental Impact & Experience *(Father's Education + Mother's Education) \\
Parental Impact-Squared & Experience* Experience *( Father's Education + Mother's Education) \\
South & Equals 1 If respondent lived in the South in 1976 \\
SMSA & Equals 1 If respondent lived in the South and in a metropolitan area in 1976 \\
SMSA-66 & Equals 1 If respondent lived in the South and in a metropolitan area in 1966 \\
Near 2-Year College & Equals 1 If 2-year accredited college in respondent's local labor market in 1966 \\
Near 4-Year College & Equals 1 If 4-year accredited college in respondent's local labor market in 1966 \\
Region & Nine regional dummies denoting respondent's region of residence in 1966 \\
Mother\&Father@14 & Equals 1 If respondent lived with mother and father at age 14 \\
Single Mother@14 & Equals 1 If respondent lived with single mother at age 14 \\
\hline
\end{tabular}

Table 2: Descriptive Statistics

US National Longitudinal Survey of Young Men (NLSYM)1966-1981

\begin{tabular}{|c|c|c|c|c|}
\hline Variable & Mean & Std. Dev. & Minimum & Maximum \\
\hline Log Wage & 6.262 & 0.44 & 4.61 & 7.78 \\
\hline Education & 13.263 & 2.677 & 1 & 18 \\
\hline Predicted Education & 13.263 & 1.44 & 8.38 & 17.46 \\
\hline Experience & 8.856 & 4.142 & 0 & 23 \\
\hline Experience-Squared/100 & 0.956 & 0.846 & 0 & 5.29 \\
\hline Predicted Experience & 8.856 & 3.474 & 1.31 & 18.02 \\
\hline Predicted Experience-Squared/100 & 0.905 & 0.68 & 0.01 & 3.25 \\
\hline Age & 28.120 & 3.14 & 24 & 34 \\
\hline Age-Squared & 800.550 & 180.75 & 576 & 1156 \\
\hline Black & 0.234 & 0.42 & 0.00 & 1.00 \\
\hline Father's Education & 7.710 & 5.33 & 0.00 & 18.00 \\
\hline Mother's Education & 9.135 & 4.47 & 0.00 & 18.00 \\
\hline Parental Education (Interaction) & 84.107 & 72.76 & 0.00 & 324.00 \\
\hline Parental Impact & 135.438 & 86.85 & 0.00 & 480.00 \\
\hline Parental Impact-Squared/100 & 13.381 & 12.90 & 0.00 & 86.64 \\
\hline Predicted Parental Impact ${ }^{1}$ & 135.438 & 79.79 & 0.00 & 425.95 \\
\hline Predicted Parental Impact-Squared/100 1 & 12.719 & 11.00 & 0.00 & 53.27 \\
\hline Mother\&Father@14 & 0.789 & 0.41 & 0.00 & 1.00 \\
\hline SingleMother@14 & 0.101 & 0.30 & 0.00 & 1.00 \\
\hline SMSA & 0.713 & 0.45 & 0.00 & 1.00 \\
\hline SMSA-66 & 0.650 & 0.48 & 0.00 & 1.00 \\
\hline South & 0.404 & 0.49 & 0.00 & 1.00 \\
\hline Near 2-Year College & 0.441 & 0.50 & 0.00 & 1.00 \\
\hline Near 4-Year College & 0.682 & 0.47 & 0.00 & 1.00 \\
\hline
\end{tabular}


Table 3: Parental Education and Wages

Dependent Variable: Log Hourly Wage

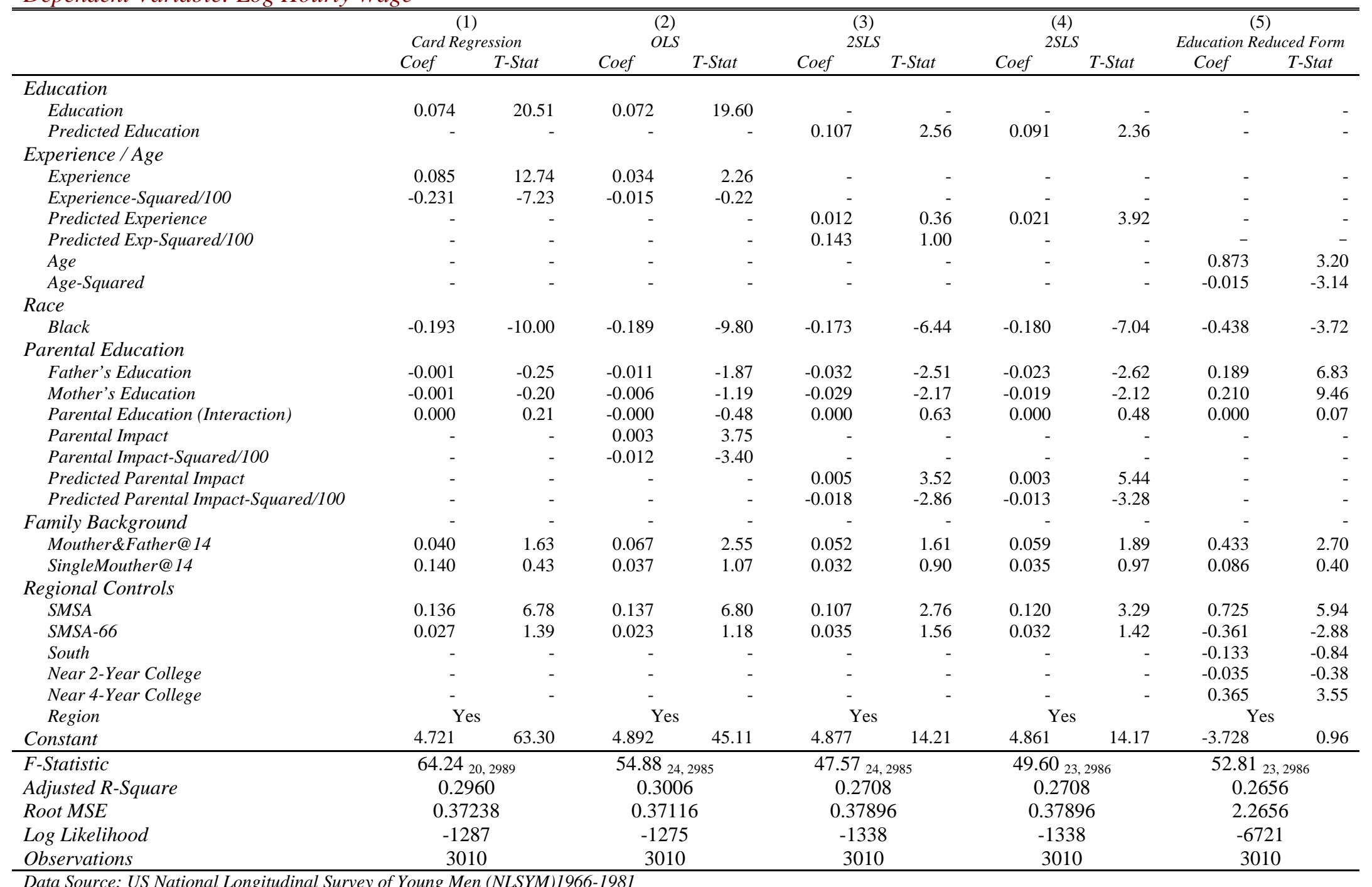

Data Source: US National Longitudinal Survey of Young Men (NLSYM)1966-1981 


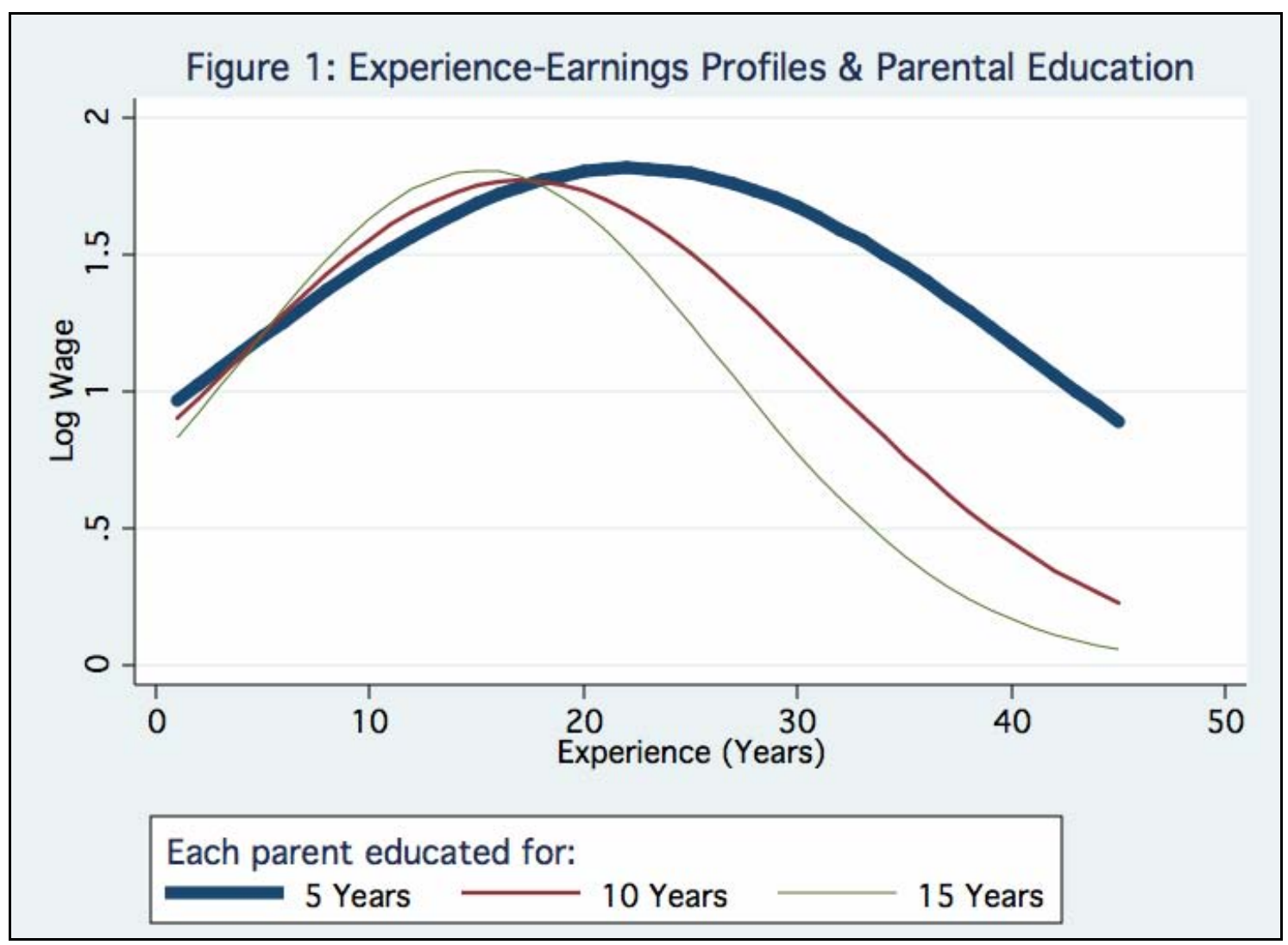

